\title{
On D Enterprise Employee Relations
}

\author{
Wenwu Li \\ School of business administration Inner Mongolia University of finance and economics, China \\ 010070
}

Iww116@126.com

\begin{abstract}
Keywords: Small enterprises; Employee relations; Employee relations management
\end{abstract}
\begin{abstract}
The paper used principle of the enterprises employee relationship management, analyse the existing problems and reasons of a small enterprises ,based on reference at home and abroad, puts forward the suitable for the improvement of the small enterprise employee relationship management advice.
\end{abstract}

\section{Overview}

The meaning of employee relations. Generally, employee relations can be divided into two aspects: broad sense and narrow sense. Broadly speaking, employee relationship refers to the relationship within the business scope of an enterprise and between groups and individuals within the enterprise, mainly including individual employee relationship, enterprise group relationship and the relationship between groups and individual employees. In the narrow sense, the scope mainly includes the relationship between employees and the relationship between enterprises and employees. in this narrow sense of employee relations, the behavior of managers and employees and their mutual influence include the relevant rights and obligations of both parties. This makes the definition of this relationship cover two meanings: first, both parties have legal relations from the legal aspect, because the labor contract signed between them has legal effect; On the other hand, it involves habits and ethics, and an unwritten social tacit understanding of interpersonal and moral righteousness.

Employee relationship management belongs to a specific field in human resource management. From a broad perspective, it is up to the enterprise management level and relevant personnel of the human resources department to formulate and carry out various policies to achieve the management of employee relations so that the enterprise can have a better future. In a narrow sense, the employee relationship is the relationship between the enterprise and its employees. Employee relationship management is a systematic management in a certain sense. various management methods should be adopted to integrate various concepts of human resource management into all aspects of management so as to arouse the enthusiasm of employees

\section{D enterprises Employee Relationship Management Status Analysis}

Overview of D enterprises' human resources. D enterprises currently has more than 200 employees, over $40 \%$ of whom are under 40 years of age. However, people in this age group also have a heavy burden on their families. it can be said that both the old and the young are likely to be dragged down by household chores, and their experiences will definitely be scattered by family affairs. For these employees, enterprises should take some measures to relieve their work and life pressure and improve their work enthusiasm. Judging from the educational background of the employees, the educational background of the employees still needs to be improved. on the one hand, it can be cultivated through the internal cultivation of enterprises, on the other hand, it can adopt the system of eliminating the worst and eliminating the worst.

Problems in Employee Relationship Management of D Enterprises. There is a general lack of humanistic care in the management of employee relations. this is mainly manifested in the following two aspects. First, the enterprise has not established sufficient respect for its employees. The enterprise generally has the phenomenon of forcing, threatening or arbitrarily dismissing 
employees. It is not aware of the labor security rights and personal rights that employees enjoy as laborers in the process of labor. Secondly, due to the lack of systematic management, the number of enterprise managers is small and their rights are highly concentrated. There is a phenomenon of simplification, non-procedure and arbitrariness in the management, which affects the employee relations of enterprises. The management of employee relations of enterprises has not achieved the requirements of standardization and legalization. Enterprises lack effective and flexible staff relationship management methods. Without corresponding legal knowledge and management knowledge, only through rigid management methods will not only arouse employees' resentment, but also increase labor disputes between enterprises and employees.

Frequent Staff Turnover and High Turnover Rate. The company's current employees are mainly post - 80s and post - 90s young people. They are active in thinking, have strong innovative consciousness, and have career aspirations. They pay attention to personality, have strong self awareness, advocate freedom and do not like constraints. This part of the staff has strong plasticity. If they are trained at work, they will easily become the backbone of the enterprise and inject new vitality into the development of the enterprise. However, this group of employees have a serious psychology of hunting for strange things. They pay less attention to the survival and development of the enterprise, and they are more concerned about the personal gains in the enterprise. If the income from the company meets their expectations within a certain period of time, they will continue to work in this enterprise, and vice verse, they will find another job.

There is no Formed Corporate Culture. The promotion of enterprise culture can effectively improve employees' work enthusiasm, increase employees' cohesion and make employees have a sense of belonging to the enterprise. However, the company only adopted some ostentatious and untrue measures. It was exquisite and complete on the surface, but in fact it only stayed in form and did not get deep into the hearts of the people. The enterprise did not set up a good vision for its employees, and at the same time did not integrate the necessary resources. as a result, employees could not achieve their personal goals through the continuous growth of the entire enterprise.

Relationship management, compared with most enterprises, this experience is still far from sufficient. The management concept and system of the whole enterprise are still imperfect. Some employees are not satisfied with the company's welfare benefits and are dissatisfied with the distribution of working hours and rest hours. They began to complain that the company is not paying enough attention to themselves. They believe that the enterprise is not fair, open and fair. Many managers always believe that the employee relationship management is not in place and that there is no clear and reasonable distribution between the management confusion responsibilities of various departments. Occasionally, employees of the company go slow, their mood is unstable, and even strikes have occurred. These are caused by the inadequate management of employee relations in the enterprise. The whole enterprise still uses primitive and crude management and does not respond correctly to various suggestions of employees. It is very easy to make employees in the opposite position of managers.

Employees' Communication Awareness is Weak. Due to the fact that the company and its employees have not established a good and perfect communication channel, it is impossible for the company to strangle these unstable factors in their infancy in time. If there are contradictions and conflicts within the employees, which directly leads to many unstable factors happening quietly. Because there is no good communication channel, most employees will choose to tolerate in response to conflicts.

Staff Cohesion needs to be strengthened. Due to regional culture, most employees of the company are local people, and some employees have some nepotism to some extent. The company wants to solve this situation by recruiting people from other countries. However, this method does take temporary solution but does not cure the root cause. Because of more or less nepotism, employees have their own small groups, and foreign personnel cannot quickly integrate into the enterprise. They may also have conflicts with the employees. In addition, the enterprise always has doubts about foreign personnel, and as a result, most foreign employees have to choose to leave. At 
the same time, because of this kind of nepotism, employees have far less attention to the company's interests than their own, resulting in tension between employees.

\section{Countermeasures to Improve Employee Relations}

Aiming at the problem of employee relationship management in D enterprise, This paper puts forward the following perfect suggestions from the following aspects, hoping that these suggestions can play a certain role in the construction of employee relationship management in other small and medium-sized enterprises in our country.

Establish a Correct Corporate Culture. The culture of the enterprise represents the direction and thinking of the enterprise. A good enterprise is undoubtedly the most fundamental motive force for its development for its corporate culture. At the same time, we can not ignore the important role of corporate culture in management, especially human resource management. Corporate culture is one aspect of corporate image display, which is also an indicator of employee satisfaction and will indirectly affect the work efficiency of employees. From this aspect, it can be seen that the management of employee relations is closely linked to the corporate culture. D enterprises should establish a correct corporate culture to promote the maintenance and improvement of employee relations.

Excellent corporate culture can maintain the harmonious relationship between employees and make the relationship between employees and the company closer. At the same time, excellent corporate culture can also improve organizational performance and encourage employees and enterprises to develop together. Therefore, in addition to striving to improve performance, excellent enterprises at home and abroad must cultivate excellent corporate culture. Therefore, the department store should absorb the experience of excellent enterprises both at home and abroad, and first solve the problem that the enterprise culture does not take shape. The enterprise should establish an enterprise culture suitable for retail enterprises based on its own characteristics. At the same time, the interests of enterprises and employees are realized through the common vision of enterprises. Without a common goal, there is a lack of faith in struggle. Therefore, the company should describe the organizational vision to employees and indicate their career development direction in the enterprise. This can not only increase the cohesion of employees in the enterprise to a certain extent, but also enable employees to see the good future, and then, under the attraction of the common vision, they will be in the same boat with the enterprise.

Clarify the Responsibilities of Managers. All levels of the enterprise should do their job well and attach importance to the management of employee relations. The senior managers of the enterprise have the main responsibility for the harmonious relationship between employees. The human resources department should guide and plan the employee relations. Judging from the case of a department store, the company has misunderstanding and is not professional in human resource management. Therefore, the company's managers should pay more attention to employee relationship management in their thoughts and actions. The decision of the company's management and the implementation method of the decision have a very important influence on the company's employees, which to a certain extent determines the management trend of the human resources department on the employee relations, and also determines the employees' opinions on the company. The directly affiliated department shall establish a suitable channel to communicate with employees, be familiar with the employees' needs for the enterprise, adopt some opinions of employees, and then give feedback to the human resources department. The human resources department will sort out and collect the feedback information, find out the starting point of execution based on the information, and form benign communication.

\section{To Ensure Effective Communication}

Failure to communicate in time brings various problems to the development of the company when conflicts arise between the case company and its employees and between employees. The company must take measures to ensure effective communication, understand the needs of employees through 
communication, and let employees work happily. This kind of communication between enterprises and employees can establish a positive employee relationship and is also an important means of information transmission. For an enterprise whose employees are always complaining, solving this situation is the most important thing. Therefore, it is suggested that the D company should encourage managers to make close contact with employees as friends. At the same time, managers should show their importance to their opinions in the process of communication with employees. In addition, managers and employees should pay attention to communication skills. Managers should not make false judgments about employees' statements. When expressing one's thoughts, one must pay attention to the way of narration. Be patient and not domineering when listening to employees' opinions. D companies can also try to communicate with employees in other ways, such as through performance interviews, transmission of job information, setting up general manager's mailbox, chat platform, etc. to encourage employees to put forward suggestions for improvement, etc.

\section{To Improve the Relevant Systems for Employees to Participate in Management}

In order to realize an effective employee participation management system, the formulation of the internal management system of an enterprise should ensure the exercise of employees' power. Internal communication and exchange affect the effective implementation of the enterprise management system. Through communication, leaders should also adopt constructive opinions of employees to find out the shortcomings of the enterprise system, so as to avoid the phenomenon of " being led" and " being involved" in the implementation of human resource management in which employees participate in management. At the same time, it is best for the enterprise to set up professional personnel to investigate the characteristics of the enterprise itself and its employees so as to guide and encourage employees to actively participate in management and ensure their independent exercise of power. For example, in Germany, the " employee participation management law" stipulates that to set up a board of supervisors in an enterprise, both employers and employees should participate in decision-making based on the principle of reciprocity. In Germany, the enterprise law stipulates that if there are more than five employees in an enterprise, a staff Committee must be set up, and its members shall be decided jointly by the employees. The number of members of the staff Committee shall be changed every three years, and the number of members of the staff Committee shall be proportional to the number of enterprises. The decision-making involves important interests, and the management must obtain the approval of the staff Committee. In addition, enterprise employees also have the right to personal participation. They can also lodge complaints when they feel that their rights have been violated. Therefore, small and medium-sized enterprises in our country should also establish and perfect the system of employees' participation in management so as to raise employees' awareness of participation in management.

In short, with the development of economy and the expansion of enterprises, human resource management, especially employee relations, will play an important role in enterprises. Establishing a good employee relationship and retaining outstanding talents are the cornerstones of the healthy growth of enterprises.

\section{References}

[1] F. Dutheil,C. Kelly,I. Biat,D. Provost,O. Baud,H. Laurichesse,A. Chamoux. Relation entre le niveau de connaissance et le taux de vaccination contre le virus de la grippe parmi le personnel du CHU de Clermont-Ferrand[J]. Médecine et Maladies Infectieuses,2008,38(11).

[2] Chiharu Miyata,Hidenori Arai,Sawako Suga. Characteristics of the nurse manager's recognition behavior and its relation to sense of coherence of staff nurses in Japan[J]. Collegian,2015,22(1).

[3] Peng L, Fang W. Heterogeneity of Inferring Reputation of Cooperative Behaviors for the Prisoners' Dilemma Game [J]. Physica A: Statistical Mechanics and its Applications, 2015, 433: 367-378. 